\title{
DEVELOPMENT OF NEW ASSORTMENTS OF PHYTOJAMS WITH INCORPORATION OF PLANT INGREDIENTS
}

\author{
Radostina Stefanova, Antoaneta Georgieva, Krasimir Krastev, Zdravko Slavov \\ Faculty of Technics and Technologies, Trakia University, Bulgaria \\ Graf Ignatiev 38, 8600 Yambol, Bulgaria, e-mail: ageorgieva@ftt.uni-sz.bg
}

\begin{abstract}
Influence is investigated of the main components of the newly developed assortments of phytojems - fruit part, vegetable ingredients, fertilizers, sweeteners and organic acids on the sensory evaluation. The main tasks in the development of the phytojams are to preserve the consistence upon addition of pectin; increasing the nutritional value of the main raw material by introducing dry and thickened plant extracts and lowering the energy value of new assortment products at the expense of reducing the amount of sugars in the recipes or replacing them with fructose. By physicochemical parameters the studied variants differ from the traditionally produced low-caloric jams with the higher content of phenolic compounds. Sensory evaluation was conducted at the ten ball system. Five model variants have been evaluated with a total sugar content of less than $10 \%$. They have better organoleptic qualities, appearance and functionality.
\end{abstract}

Key words: phytojams, plant ingredients, organoleptic qualities, functionality.

\section{INTRODUCTION}

The role of healing and prophylactic nutrition is growing.

Studies conducted in different countries confirm that one of the major causes of pathological changes in the human body leading to premature aging and development of cardiovascular diseases, oncological diseases and diabetes is the excessive accumulation in the biological fluid of free radicals and active forms of oxygen (superoxide, hydrogen peroxidation and hydroxyl radicals).

Increasing the content of free radicals in the cells creates conditions for the oxidative stress, in which free radicals oxidize vessel walls, protein molecules, DNK and lipids. These radicals actively interact with membranes of lipids containing unsaturated bonds and alter the properties of cell membranes [1].

Hydroxyl free radicals are high energy, short-acting and very toxic. The toxicity of hydrogen peroxide and the superoxide anion are also related to their possible conversion by formation of a hydroxide radical.

Most of the natural antioxidants enter the human body with food. With systemic use of food products containing natural antioxidants, the morbidity of the population from cardiovascular and oncological diseases is significantly reduced.

Regular use of fruits and berries, where there are many natural phenolic compounds, greatly reduces the risk of these diseases. The greatest amount of antioxidants are contained in the fruits of rosehip, blackberries, grapes, bilberry, strawberry and others. It is therefore necessary to include natural plant antioxidants in the composition of foods that protect them from oxidation.

In order to increase the nutritional value and antioxidant properties of the gems, extracts of wild-growing raw materials having a prophylactic and functional effect can be introduced into the production technologies.

Extracts serve as natural antioxidants.

The healing potential of wild growing bushy plants is their antioxidant, anti-allergic, antiinflammatory and anti-viral properties, which depend on polyphenol complexes. Particular attention is paid to the content of flavonoids and anthocyanin pigments.

Fruits and berries supply the human body with the necessary vitamins, mineral substances,

IRTIIE Vol. 6, No. 2, 2018 ISSN 1314-8788 (print), ISSN 1314-8796 (online), doi: 10.15547/artte.2018.02.014 


\section{ART'TE

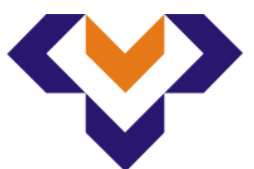 \\ Ipplied Researthes in Technics, Technologies and Bduration \\ Journal of the Faculty of Technics and Technologies, Trakia University https://sites.google.com/a/trakia-uni.bg/artte/}

polyphenol compounds, organic acids, carbohydrates, incl. fiber - cellulose and pectin.

Jams are a good source of these substances for the body. The production of this assortment is one of the methods of preserving fruits and berries.

The aims of the present study is to develop new assortments of low energy jems meeting the requirements for curative and prophylactic nutrition and to determine the influence of the component composition on the basic physicochemical parameters and sensory evaluation.

\section{MATERIALS AND METHODS}

Based on the definitions in the European Directive 79/693, formulations and technologies for producing low energy jams have been developed.

In developing the technologies, are used plant ingredients to produce new assortments of jams with targeted action. Mixtures of fruits and berries are used. A new direction in the production of phytojams is the use of plant extracts.

Low-esterified pectin preparations are used to obtain a normally gelled mixture. Of the organic acids citric acid (E330) is used to adjust the $\mathrm{pH}$ and improve the taste of lowsugar products. Ascorbic acid is added as an antioxidant. Sorbic acid is used as a preservative.

The physicochemical and sensory analyzes were conducted using standardized, modern methods approved by good manufacturing practice.

- General Phenol Compounds (AFS) spectrophotometric method with Folin-Denisa reagent, \% as gallic acid [2].

- Phenol Carbonic Acid - Spectrophotometric by Pharmacopoeia Method [Pharmacopoeia Russia]. General method of analysis [2].

- Flavonoid phenolic compounds - spectrophotometric as a rutin,\% by pharmacopoeial method [Pharmacopeia Russia]. General method of analysis [2].

- Anthocyanins - spectrophotometric such as cyanidine-3,5-diglucoside, by pharmacopoeial method [Pharmacopoeia Russia]. General method of analysis [2].

- Tanning substances - titrated with $0.02 \mathrm{M}$ potassium permanganate, $\%$ by pharmacopoeial method [Pharmacopoeia Russia]. General method of analysis [2].

- Ascorbic acid - titration of 0,001M sodium chloride 2,6-dichlorophenolindophenol, $\mathrm{mg} \%$ BDS 11812-91.

- Carotenoids - spectrophotometric as $\beta$-carotene, $\mathrm{mg} \%$ by pharmacopoeial method [Pharmacopoeia Russia]. General method of analysis [2].

- Free Organic Acids - Titration, Pharmacopoeial Method [Pharmacopoeia Russia]. General method of analysis [2].

- Vitamin P - bioflavonoid (rutin, citrine, catechins, etc.) is a complex of compounds called bioflavonoids [2].

- Pectic substances,\% BDS 16591:1987.

\section{RESULTS AND DISCUSSION}

Apples, pears, plums, black currants, blackberries containing no more than $10 \%$ sucrose and glucose were used. Pumpkin was used from vegetables. Forest fruits contain many biologically active substances and have a wide range of physiological effects on the human body.

The technology for obtaining extracts of cranberry and black currant has been developed.

The fruit of Vaccinium myrtillus L. contains many sugars (fructose and glucose predominate and sucrose is insignificant), pectin substances, organic acids (malic, citric, tartaric, lactic, succinic, oxalic, quinine, etc.).

The fruit has a diverse mineral composition. Contains macro and many microelements. Of all

IRTIIE Vol. 6, No. 2, 2018 ISSN 1314-8788 (print), ISSN 1314-8796 (online), doi: 10.15547/artte.2018.02.014 


\section{ARTTE $Y^{2}$}

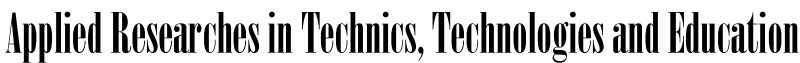

Journal of the Faculty of Technics and Technologies, Trakia University https://sites.google.com/a/trakia-uni.bg/artte/

fruits, the fruit of the bilberry has the highest manganese content.

Contains glycosides (myrtilin, neomycin, vaccinin, ericolin, arbutin, isocvercetine, avicularin) and anthocyanins. Myrtlein and neomycin, which can lower blood sugar in diabetes mellitus, are involved in their composition.

The fruit of Ribes nigrum is a natural vitamin concentrate, especially with its high levels of vitamin $C$, vitamin $P$ and $\beta$-carotene.

In this respect, superior many fruits, including lemons, sugars are mainly fructose and glucose.

The cassis fruit is rich in organic acids - citric, malic, oxalic, succinic, fumaric and caffeic, chlorogenic and salicylic, quinic, tartaric and nicotinic acids.

Contains many pectin and dye substances. The fruit is rich in mineral substances, macroand microelements, glycosides and amino acids.

Dyestuffs together with calcium salts and organic acids have a stabilizing effect on vitamin $\mathrm{C}$ and protect against viral infections with flavonoids.

Three groups of substances refer to vitamin P: flavones, anthocyanins and L-catechins. In nature, these groups mutually convert, and the flavonols via leucoanthocyanidins can be converted to either anthocyanidins or catechins. The process of transformation continues, so that in the world of plants these groups become one another.

Anthocyanins refer to the P-active substances - red-colored substances contained in the wild plants studied. The amount of beneficial substances, vitamins and minerals is higher than other fruits. Therefore, they are considered to be products of healthy and rational nutrition, they help to increase immunity, heal and strengthen the body and are useful in various diseases.

As the basis for the phytojams are chosen the most common fruits and vegetables: apples, pears, plums and pumpkin. They all unite in that they contain in their composition pectic substances, which are included in the group of dietary fiber, which assign their special role to the healing and prophylactic diet.

In the opinion of experts from the World Health Organization and the UN World Food and Agriculture Organization, pectin supplements can be used without quantitative restrictions. The best physiological effect the pectin manifests in a hydrated form in which it preserves its maximum complexing ability.

In accordance with rational nutrition, the content of pectin substances in the 24-hour portion should be $5-6 \mathrm{~g}$. Particularly high is the ability of pectin to bind industrial poisons, heavy metal salts, radionuclides, and the like. substances. The research of various authors has shown that preserved fruit products preserve the high complexing ability of pectin in which pectin loses its activity in terms of lead ions to $50 \%$.

In case of a disease with varying degrees of pathological alteration, further administration of pectin is required. An additional dose of pectin may be administered in portion as an extract, concentrate or as a finished product of therapeutic or prophylactic importance. The selected fruits also have specific features.

The physicochemical composition of the fruits used was investigated.

Apples promote good digestion. They increase the ability to radiate and strengthen immunity. Apples contain the necessary substances for the normal functioning of the body. An indispensable component that promotes metabolism in the body are organic acids. Their percentage in apples is $1.6 \%$, but only in apples are contains simultaneously malic, succinic, citric, oxalic and acetic acid.

Pectin in apples is $1.8 \%$. This makes apples a healing product. Pectin in combination with cellulose and tanning substances accelerates the removal of slag from the body and helps to quickly neutralize and remove heavy metals lead, cobalt and strontium.

Apples contain phenolic compounds, a saturated active form of vitamin P - $233 \mathrm{mg} \%$. Tannins have anti-inflammatory action and are used for gastrointestinal disorder. Catechins have high P-vitamin activity. The average catechins content is $0.9 \%$. Tannins and dyeing

IRTIIE Vol. 6, No. 2, 2018 ISSN 1314-8788 (print), ISSN 1314-8796 (online), doi: 10.15547/artte.2018.02.014 


\section{ARTTIE $Y$}

Ipplied Resseirlohes in Technics, Technologies and Bductation

Journal of the Faculty of Technics and Technologies, Trakia University https://sites.google.com/a/trakia-uni.bg/artte/

substances give the fruits acerp taste and contribute for the better clarification of juice.

It has been found that apples contain a small amount of vitamin $\mathrm{C}$, vitamin $\mathrm{P}$, provitamin $\mathrm{A}-$ $0,07 \mathrm{mg} \%$. Fetus contains up $25 \mathrm{mg} \%$ of ascorbic acid.

Pears have a diuretic and reinforcing effect. Recommended for renal stone disease and dysentery.

The content of organic acids in pears is $0,6 \%$. Malic acid and chlorogenic acid predominate. The amount of citric acid, coffeic acid, quinine acid and boric acid is negligible. These acids have a capillary strengthening and bile duct action. Pears contain a small amount of vitamin C - $8 \mathrm{mg} \%$, vitamin $\mathrm{P}-580 \mathrm{mg} \%$ and $\beta$-carotene $-0.08 \mathrm{mg} \%$.

Fruits are rich in phenolic compounds and have a capillary and anti-sclerotic effect. This group of substances includes catechins, leucoanthocyanins, flavonoids and phenolic acids.

The content of tanning substances in pears is $0.08 \%$.

Plum contains many biologically active substances. Fruits contain organic acids $-2.9 \%$, pectin $-1.8 \%$ and tanning substances $-0.15 \%$. Organic acids are represented by malic and citric acids. Small amount are contain oxalic acid, succinic acid, quinic acid and traces of salicylic acid methyl ester. he vitamin C content in the fetus is $10 \mathrm{mg} \%$. They contain phenolic compounds, predominantly flavonols (quercetin, isobercitin, etc.), anthocyanins and leucoanthocyans, a saturated active form of vitamin P - $500 \mathrm{mg} \%$. Plums contain $2.8 \mathrm{mg} \%$ of $\beta$-carotene. Most caroten contain the yellow plums. The nutritional value of the fruits depends on their chemical composition, which varies according to maturity, variety, climatic and soil conditions, and agro-technology.

The gourd contains organic acids $-0.2 \%$ and pectin substances $-1.4 \%$. The vitamin $\mathrm{C}$ content in the fetus is $13 \mathrm{mg} \%$. It contains phenolic compounds, a saturated active form of vitamin $\mathrm{P}-184 \mathrm{mg} \%$. Pumpkin contains $3.2 \mathrm{mg} \%$ of $\beta$-carotene.

The research of the fruits of Vaccinium myrtillus and Ribes nigrum shows that they contain many biologically active substances /phenolic and vitamin complexes/ and are suitable for production of functional products [3].

The main tasks in the development of the phytojams are to preserve the consistence upon addition of pectin; increasing the nutritional value of the main raw material by introducing dry and thickened plant extracts and lowering the energy value of new assortment products at the expense of reducing the amount of sugars in the recipes or replacing them with fructose.

Phytojams are prepared using traditional technology, but with a reduced amount of sugar in the recipe. This reduces the energy value of the product, which is relevant to modern nutrition.

In order to maintain the consistence of the phytojams the same, at reducing the amount of sugar, in the jam at the end of digestion, an additional amount of prepared pectin is introduced simultaneously with the introduction of the plant extracts.

Introduced extra pectin enhances the protector properties of the phytojams, due to the presence of native pectin substances in the main raw material.

The introduced plant ingredients influence the organoleptic characteristics taste and color of the phytojams. All the phytojams have different shades of brown color, from light brown to dark brown.

It depends on both the amount of the introduced plant ingredient and the color of the main raw material. Plant ingredients give the fruits a specific flavor and aroma. The dry matter content of the developed phytojams has a wide range of 10 to $15 \%$.

In order not to reduce the dry matter content, sucrose is replaced by fructose, which has a sweetness ratio lower than that of sucrose [4].

Sensory evaluation in model experiments with jams of different fruits and plant ingredients is a basic method for determining the acceptability of low-sugar products. These assessments include recommendations for changes to the component formulation for the respective assortments.

IRTIIE Vol. 6, No. 2, 2018 ISSN 1314-8788 (print), ISSN 1314-8796 (online), doi: 10.15547/artte.2018.02.014 


\section{IRITIE}

Conducting new experiments led to the production of model products with the desired transparency, shine and color. On this basis, the developed jams are subjected to a sensory evaluation for choosing optimal formulations of recipes. The sensory evaluation data is shown in Figure 5.

The main physico-chemical indicators of the developed jams are presented in Table 1, and Figures 1-4. Characteristic feature of the products studied is the content of phenolic compounds increasing the anti-radical activity of the products. With this, the main goal of the development was achieved - creating new assortments of jams with the lowest sugar content and functional properties possible. The main share of this content is the presence of sugars in the fruit used.

Table 1. Physico-chemical indicators of low sugar jams

\begin{tabular}{|l|c|c|c|c|c|}
\hline \multicolumn{1}{|c|}{ Indices } & Variant 1 & Variant 2 & Variant 3 & Variant 4 & Variant 5 \\
\hline Phenolic compounds, \% & 3,8 & 2,9 & 4,7 & 5,2 & 5,5 \\
\hline $\begin{array}{l}\text { Flavonoid phenolic } \\
\text { compounds, mg\% }\end{array}$ & 610 & 408 & 304 & 425 & 565 \\
\hline $\begin{array}{l}\text { Amount of anthocyanins, } \\
\text { mg\% }\end{array}$ & 207 & 289 & 186 & 228 & 276 \\
\hline Phenolcarboxylic acids, \% & 0,94 & 0,56 & 0,89 & 0,95 & 1,07 \\
\hline Vitamin C, mg\% & 341 & 308 & 256 & 382 & 346 \\
\hline$\beta$-Carotene, mg\% & 25 & 37 & 29 & 43 & 35 \\
\hline Vitamin P, mg\% & 750 & 798 & 908 & 547 & 845 \\
\hline Pectin, mg\% & 0,96 & 1,55 & 1,15 & 1,35 & 1,58 \\
\hline Organic acids, \% & 4,8 & 4,6 & 4,2 & 3,6 & 4,5 \\
\hline Tannins, \% & 12,1 & 15,9 & 11,2 & 10,5 & 13,4 \\
\hline
\end{tabular}

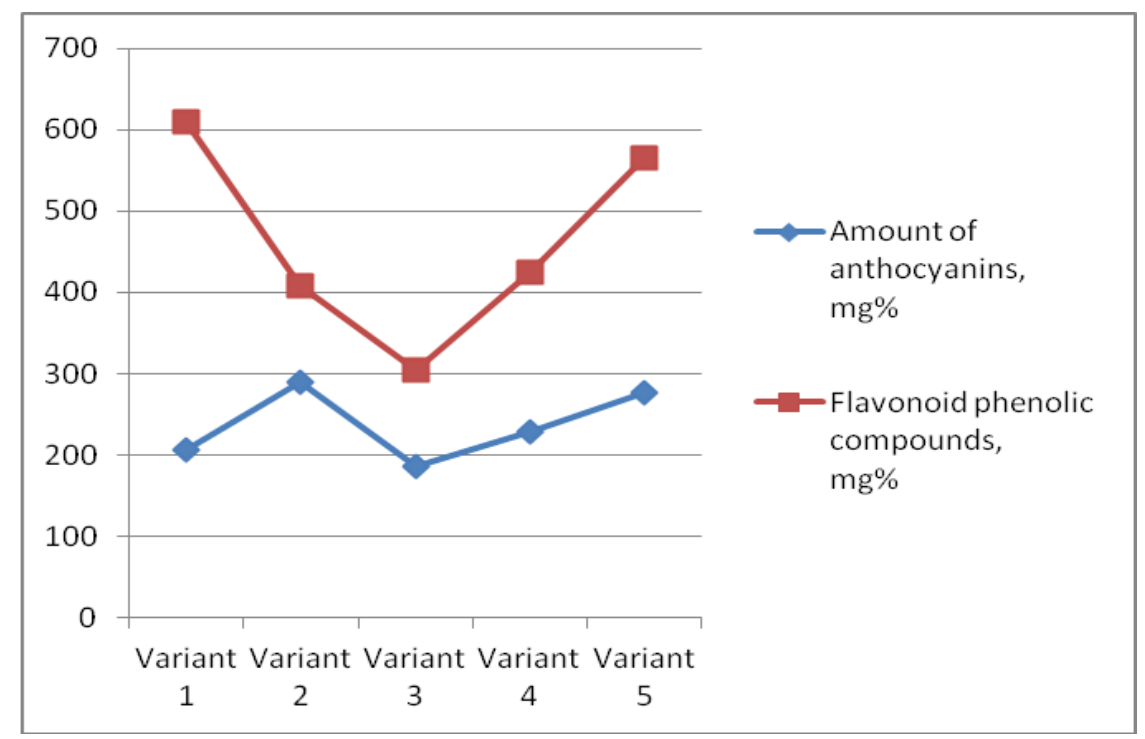

Figure 1. Study of flavonoid phenolic compounds and the amount of anthocyanins in model phytojams

Anthocyanins are water-soluble plant pigments that determine the red, blue, and violet color of the products. They are glycosides of flavonium aglycons (anthocyanidins). The anthocyanins' quality composition is specific for individual plant species. The anthocyanin content is highest in variants 2 and 5, respectively $289 \mathrm{mg}$ and $276 \mathrm{mg}$ and the lowest for variant $3-186 \mathrm{mg} \%$.

IRTIIE Vol. 6, No. 2, 2018 ISSN 1314-8788 (print), ISSN 1314-8796 (online), doi: 10.15547/artte.2018.02.014 


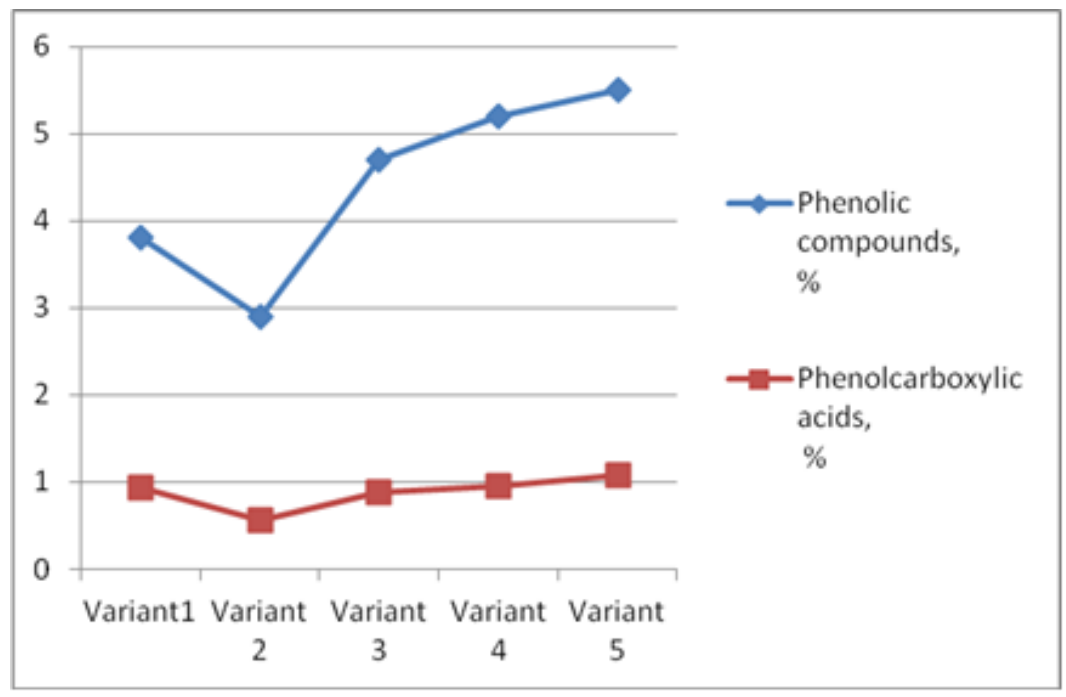

Figure 2. Investigation of the general phenolic compounds and phenolic acids in the model phytojams

The results of the conducted studies show that variant 5 has the highest content of total phenolic compounds. The content of phenolic compounds in the studied model phytochemicals is determined by the Folin-Denisa reagent. Phenolic compounds determine the color, flavor, aroma of the products. They remove the ions from the body of heavy metals and have antioxidant activity.

The trend in the phenolic acid content is similar to that for the total phenolic compounds. The concentration of phenolic compounds is highest for variant $5-1.07 \%$ and lowest for variant 2 $-0.56 \%$. The highest is the content of flavonoid phenolic compounds in variants $1-610 \mathrm{mg} \%$ and in variant $5-565 \mathrm{mg} \%$. Twice the content of flavonoid phenolic compounds in the model phytojams - variant 1 is higher than in variant 3 .

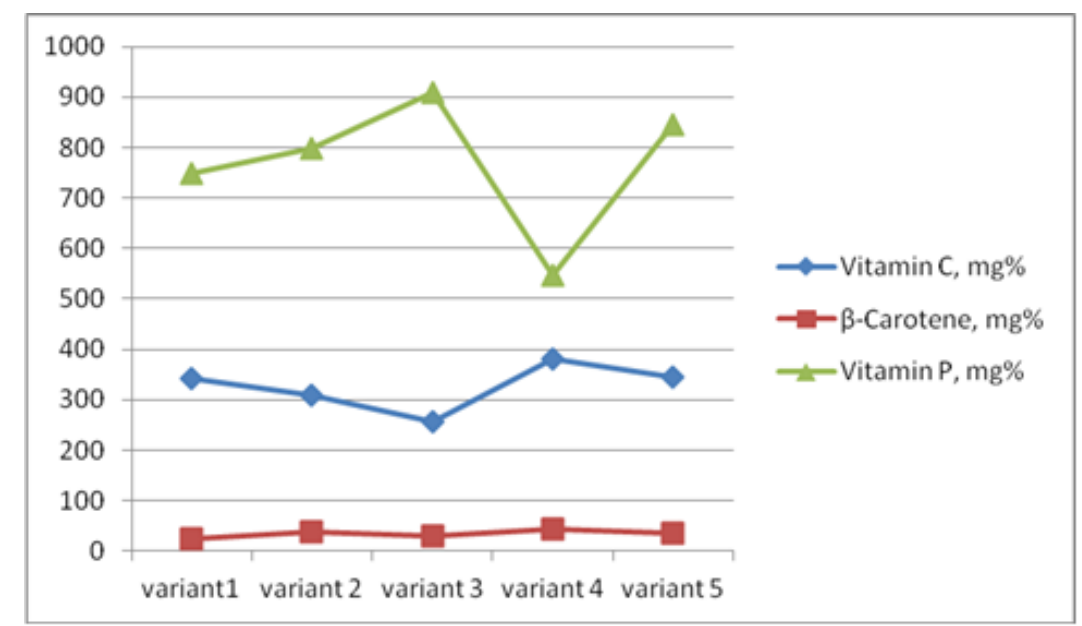

Figure 3. Study the content of vitamin C, $\beta$-carotene and vitamin $P$ in model phytojams

The nutritional value of model phytojams is also determined by the vitamins contained therein. As is evident from table 1 the test products contains ascorbic acid from $256 \mathrm{mg} \%$ to $382 \mathrm{mg} \%$ and $\beta$-carotene from $25 \mathrm{mg} \%$ to $43 \mathrm{mg} \%$. The highest $P$ vitamin activity have the phytojams 3 and 5 . They contain a significant amount of vitamin $P$, respectively $908 \mathrm{mg} \%$ and $845 \mathrm{mg} \%$, as a result of the higher black currant content in the formulations.

IRIIIE Vol. 6, No. 2, 2018 ISSN 1314-8788 (print), ISSN 1314-8796 (online), doi: 10.15547/artte.2018.02.014 


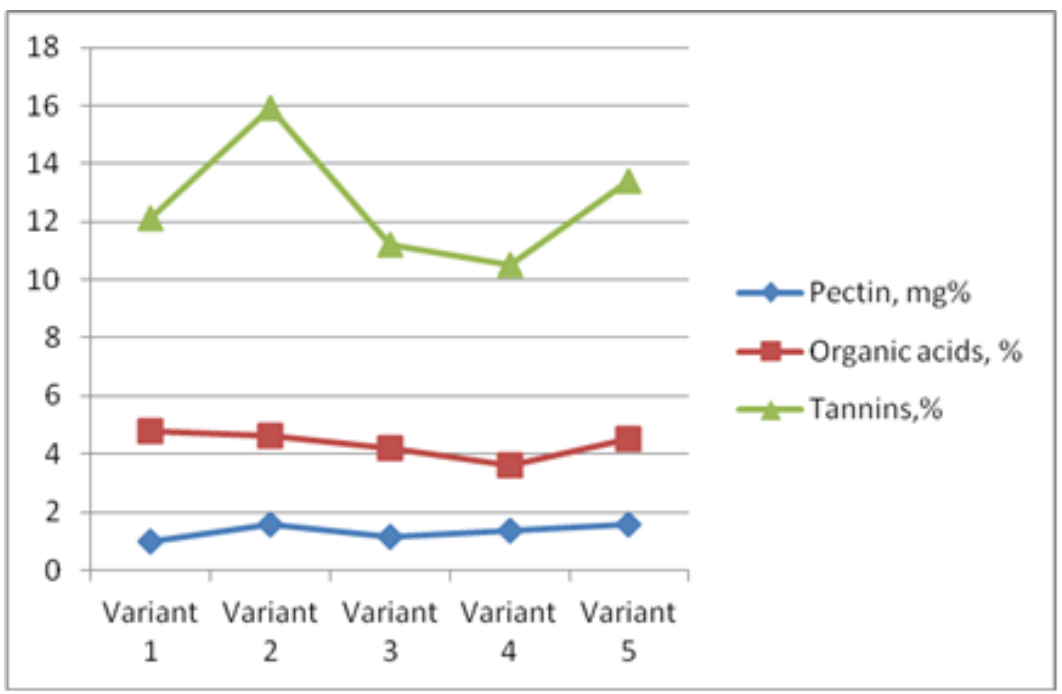

Figure 4. Study of tannins, organic acids and pectin in model phytojams

The change in tannins concentration follows the trend observed with anthocyanins from the phenolic complex. The highest is the content of tanning substances in variants 2 and 5 , $15.9 \%$ and 13.45 respectively. There is no great difference in the content of tannins in the five variants developed. Similar is the trend in organic acids.

From the studies carried out on the phytojams it is evident that the pectin content is highest in the variants in which the fruit of the apple and the pumpkin prevail, respectively variants 2 and 5 .

The organic acid content of the phytochemicals studied ranged from $3.6 \%$ to $4.8 \%$. They play an important role in the storage of the phytojams, increase their shelf life, preserve acidic taste, stimulate pancreatic secretion, stimulate intestinal peristalsis and have bactericidal action.

The comparative assessment of the best variants of jam shows that the five variants presented are accepted - Figure 5.

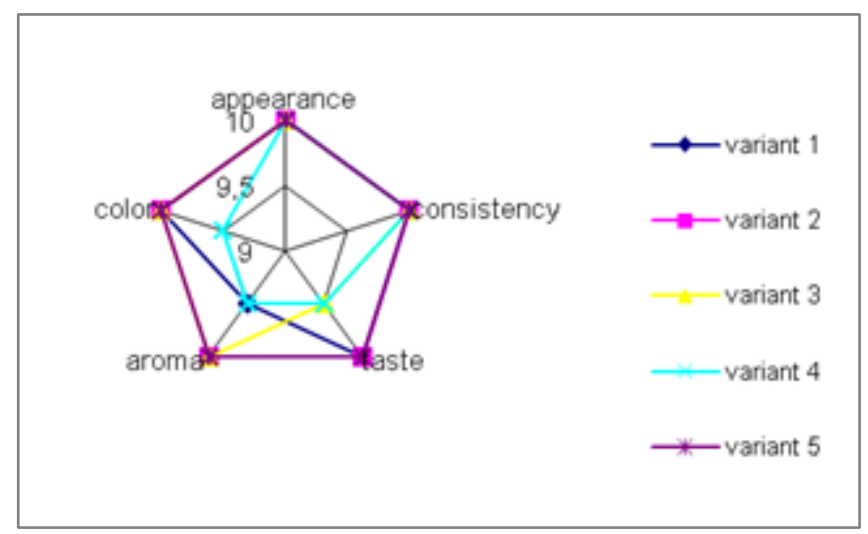

Figure 5. Sensory evaluation of model phytojams

The phytojams developed can be sterilized, non-sterilized (hot spill) and sorbic acid preservative.

Sorbic acid is added in recommended quantities in the phytojams. Sorbic acid has been recognized by the World Health Organization as a safe preservative that has a positive impact on immunity.

IRTIIE Vol. 6, No. 2, 2018 ISSN 1314-8788 (print), ISSN 1314-8796 (online), doi: 10.15547/artte.2018.02.014 


\section{ARTTIE $Y$}

Ipplied Resseirl'hes in Teednicis, Technologies and Bductition Journal of the Faculty of Technics and Technologies, Trakia University https://sites.google.com/a/trakia-uni.bg/artte/

The good taste and dietary qualities of the new assortments of low sugar phytojams enriched with biologically active substances are suitable for curative and prophylactic nutrition are presented in Table 2.

Table 2. Functional orientation of the phytosyntheses

\begin{tabular}{|c|l|l|l|}
\hline Variant & $\begin{array}{l}\text { Name of the main } \\
\text { raw material }\end{array}$ & \multicolumn{1}{|c|}{$\begin{array}{c}\text { Plant ingredients } \\
\text { fruits }\end{array}$} & $\begin{array}{l}\text { Functional orientation of the } \\
\text { phytosyntheses }\end{array}$ \\
\hline 1 & Pears & $\begin{array}{l}\text { Blackcurrant extract; } \\
\text { Black Blueberry extract }\end{array}$ & $\begin{array}{l}\text { A source of vitamins and } \\
\text { antioxidants that stimulate the work } \\
\text { of all systems }\end{array}$ \\
\hline 2 & Apples & $\begin{array}{l}\text { Blackcurrant extract; } \\
\text { Black Blueberry extract }\end{array}$ & $\begin{array}{l}\text { Immunomodulatory; } \\
\text { Total fastening. }\end{array}$ \\
\hline 3 & Plums & $\begin{array}{l}\text { Blackcurrant extract; } \\
\text { Black Blueberry extract }\end{array}$ & $\begin{array}{l}\text { Stimulates and improves } \\
\text { metabolism; Toning and cleansing }\end{array}$ \\
\hline 5 & Pumpkin & $\begin{array}{l}\text { Blackcurrant extract; } \\
\text { Black Blueberry extract } \\
\text { Blackcurrant extract; } \\
\text { Black Blueberry extract }\end{array}$ & $\begin{array}{l}\text { Total fastening in case of illness at } \\
\text { digestive and respiratory system }\end{array}$ \\
\hline 5 & $\begin{array}{l}\text { Apples, pears } \\
\text { and pumpkin }\end{array}$ & \multicolumn{2}{|l}{} \\
\hline
\end{tabular}

\section{CONCLUSIONS}

Based on the complex physical and chemical studies of phytojams is established they are found to contain many biologically active substances, a significant phenolic and vitamin complex which determines not only their high nutritional value but also their antiradical activity.

On the basis of these studies, recipes have been developed for model phytojams with very good organoleptic properties, allowing their antioxidant properties to be improved and used as functional foods.

\section{LITERATURE}

[1] Yashin Y. I. (2009). Natural antioxidants. Content in Food Products and Their Impact on Health and Human Aging, ed. Trans Leth, 2009, p. 212.

[2] State Pharmacopoeia of Russia. General methods of analysis - II ed., Medicine. 1987.

[3] Stefanova R., Georgieva A., Krastev K. (2017). Investigation of the biologically active substances contained in forest fruits for the purpose of using them as a raw material for the production of functional beverages. ARTTE Applied Researches in Technics, Technlogies and Education, Vol.5, No. 4, pp. 312-319, ISSN 1314-8796.

[4] Perkin Joanna. (1993). All Sweetnees \& Light, Food Processing, 1993, 4, pp. 41-43. 